\title{
非圧縮粘性流れの 3 次上流有限要素シミュレーション THIRD-ORDER UPWIND FINITE ELEMENT SIMULATION OF INCOMPRESSIBLE VISCOUS FLOWS
}

\author{
近藤典夫*, 西村敏雄**, 加 納充浩*** \\ Norio KONDO, Toshio NISHIMURA and Mitsuhiro KANO
}

\begin{abstract}
A third-order upwind finite element scheme for direct numerical simulation of high Reynolds number flows is presented. The scheme is proposed based on both the Petrov-Galerkin formulation and the mixed method which enables to use the linear elements. Numerical dissipation added into the scheme is expressed by the fourth-differentials with respect to the flow velocities, so that accuracy of the discretization for the advection therms becomes a third-order. Numerical results of flows in a cavity are presented to illustrate the effectiveness and robustness of the proposed upwind scheme.
\end{abstract}

Key wards: third-order upwind scheme, Petrov-Galerkin formulation, mixed formulation, finite element method

3 次上流スキーム、ペトロフ・ガラーキン表現、混合表現、有限要素法

1.はじめに

建築物は、居住性、機能性そしてデザィンの観点から 多彩な形態をむって作られており、建築物に係る多くの 流体現象を把握しておくことは極的て重要なことであ る。この流体に関する研究体系は、実験的アプローチと 平行して、スーパーコンピュータの発達と效果的な計算 手法の開発に相まって、数值流体力学という名の下に発 展し、多くの数值計算 ${ }^{1)}$ が行われてきた。建築工学の分 野に関する流体は、非圧縮性の条件を課すことができる ので、非圧縮性ナビエ・ストークス方程式と連続方程式 によって支配される。このナビエ・ストークス方程式は強 い非線形性を有しており、差分法か有限要素法を使って 離散方程式に変換されることが多く、この結果、時間に 関する連立常微分方程式として再構成される。そして、

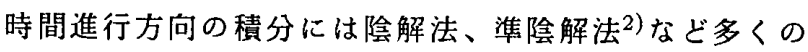
数值時間積分を適用して数值解が求められている。 離散方程式を作るとき、差分法では中心近似、有限要
素法ではガラーキン法を使うと、計算された解は数值的 に不安定となり的確な解を得ることができない。これは 高レイノルズ数領域において特に顕著となる。そのため に、数值粘性項をナビエ・ストークス方程式の中に付加 し、数值解の安定化を計ることが行われている。差分法 では、4 階 3 次の数值粘性 ${ }^{3), 4)}$ がよく使われており、こ れによって、移流項は上流化が計られている。田村ら5) は、この 3 次上流差分スキームを適用して円柱まわりの 流れの計算を行い、抗力が急激に低下する臨界レイノル ズ数を捉えるとともに、流れの 2 次元と 3 次元構造の相 違を明らかにした。

有限要素法ではペトロフ・ガラーキン法6)-15)かテーラ

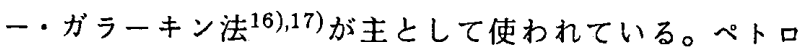
フ・ガラーキン法では、修正重み関数へ適用する形状関数 と末知関数へ適用する形状関数が異なったものとして定 義される。このような中で Streamline Upwind/PetrovGalerkin $^{12)}(\mathrm{SUPG})$ スキームが幅広く使われてきた。こ

*日本大学理工学部海洋建築工学科 専任講師 - 博 Assist., Prof., Dept. of Oceanic Architecture and Engineering, 士 (工学)

** 日本大学理工学部海洋建築工学科 教授・博士 (工学)

*** 日本大学大学院理工学研究科海洋建築工学専攻 大学院生・修士 (工学)

College of Sience and Technology, Nihon Univ., Dr. Eng.

Prof., Dept. of Oceanic Architecture and Engineering, College of Sience and Technology, Nihon Univ., Dr. Eng.

Graduate Student, Graduate School of Nihon Univ., M. Eng. 
のスキームの特徴は、修正重み関数の中の摄動関数が標 準重み関数の 1 階の空間微分に比例した量で与えられ、 数值粘性が流れの方向にのみ作用することにある。一方、 文献 6)-8) で、ペトロフ・ガラーキン法に基づいた 3 次 精度の上流有限要素スキームが示された。この手法は、 摂動関数を標準重み関数の 2 階と 3 階の空間微分の和て 与えている。2 階微分項は、移流項の離散化にともなう 2 次の打ち切り誤差を消去する働きがある。この結果、 移流項の離散化は 4 次精度の中心近似のむのとなる。3 階微分項は移流項と結びっいて、4 階 3 次の数値粘性を 作る働きがあり、その数值粘性は文献 3）と4）の上流差 分スキームの数值粘性と同じ性質を持つことが示されて いる。したがって、現在まで多用されてきた SUPG ス キームあるいは Balancing Tensor Diffusivity(BTD) と いう人工粘性を導入したスキームでは、高レイノルズ数 域で計算された解は搪散的になるが、3 次上流有限要素 スキームは高レイノルズ数域であ適切な解を与えるとい う利点がある。

本論文では、この 3 次上流有限要素スキームにより、 非圧縮粘性流れの移流卓越問題に関して、安定にしかも 精度良く解を計算できること、そしてこのスキームが非 王縮性ナビエ・ストークス方程式の計算手法としてたい へん有効である事を示す。

ナビエ・ストークス方程式と連続方程式を用いて有限 要素近似を行う時、一般に圧力のポアソン方程式はこれ らの有限要素方程式から離散型方程式(2),6)-8),12) として導 かれる。しかし、本論文ではナビエ・ストークス方程式 の発散をとり、圧力のポアンン方程式を誘導した後で、 有限要䋈近似を行う。これにより圧力のポアソン方程式 へ適用する形状関数は、流速と同じものを使うことがで き、本論文ではこれによる計算手法を示す。

具体的な数值計算例として、流体現象の基本的な問題 として知られているキ+ビィティ内流れと水路付きキャ ビィティ内流れを取り上げ、高レイノルズ数領域での流 れの様子を示す。

\section{2. 基本式}

非圧縮粘性流体の運動を支配しているナビエ・ストー クス方程式と連続方程式は、無次元表示で以下のように 与えられる。

$$
\begin{aligned}
u_{i, t}+u_{j} u_{i, j} & =\sigma_{i j, j}+f_{i} \\
u_{i, i} & =0
\end{aligned}
$$

ここで、 $u_{i}$ は流速、 $\sigma_{i j}$ は全応力、 $f_{i}$ は外力を示し、 ()$_{, t}=$ $\partial / \partial t 、()_{, i}=\partial / \partial x_{i}$ である。また $t$ は時間、 $x_{i}$ は座標変 数を表す。

全応力 $\sigma_{i j}$ は

$$
\sigma_{i j}=-p \delta_{i j}+\frac{1}{R e}\left(u_{i, j}+u_{j, i}\right)
$$

で表され、 $p$ は圧力、Re はレイノルズ数である。

一方、式 (2-1) の発散を取ることにより、以下のよう な玨力のポアソン方程式を得ることができる。

$$
p_{i i}=-\tilde{u}_{i, i}
$$

ここで、

$$
\tilde{u}_{i}=u_{i, t}+u_{j} u_{i, j}-\frac{1}{R e}\left(u_{i, j}+u_{j, i}\right)-f_{i}
$$

である。

\section{3 次上流有限要素スキーム}

非圧縮性ナビエ・ストークス方程式の適切な数值解を 作るためには、離散スキームの上流化を行うことが必要 となる。ここでは、その上流化手法の一つである 3 次上 流有限要素法について、文献 7) に沿って説明する。

3 次上流スキームは、4階 3 次の数值粘性を付加した スキームである。有限要素法を使ってこれを達成するた めにペトロフ・ガラーキン法を採用し、修正重み関数を 以下のように定義する。

$$
\bar{u}_{i}=w_{i}+\tilde{w}_{i}
$$

ここで、 $w_{i}$ は標準重み関数で、 $\tilde{w}_{i}$ は㨠動関数を表す。こ れより、ナビエ・ストークス方程式のペトロフ・ガラー キン表現は次式のように表される。

$$
\begin{gathered}
\int_{\Omega} w_{i}\left(u_{i, t}+u_{j} u_{i, j}\right) d \Omega+\int_{\Omega} w_{i, j} \sigma_{i j} d \Omega \\
+\int_{\Omega} \tilde{w}_{i}\left(u_{i, t}+u_{j} u_{i, j}-\sigma_{i j, j}-f_{i}\right) d \Omega \\
=\int_{\Gamma} w_{i} \sigma_{i} d \Gamma+\int_{\Omega} w_{i} f_{i} d \Omega
\end{gathered}
$$

連続方程式 (2-2) の重み付き残差表現は

$$
\int_{\Omega} q u_{i, i} d \Omega=0
$$

である。ここで、qは標準重み関数である。また圧力の ポアソン方程式 (2-4)の重み付き残差表現は、標準重み 関数を竐として以下のようになる。

$$
\int_{\Omega} \bar{p}_{, i} p_{, i} d \Omega=\int_{\Omega} \bar{p} \tilde{u}_{i, i} d \Omega+\int_{\Gamma} \bar{p} p_{, i} n_{i} d \Gamma
$$

物理現象を数值的に計算するとき、解の解像度を高め るために解析領域を不等メッシュに分割することが多い。 しかしこのょうな不等メッシュの下で作られた有限要菜 方程式は、離散化に伴う打ち切り誤差のオーダー評価を すると、1 次精度のものとなる。そこで精度を高めるた めには、有限要素法の場合でも差分法と同じょうに、写 像空間の中で離散化を行うことが必要になる。

物理烲間 $\left(x_{i}, t\right)$ から計算空間 $\left(\xi_{i}, \tau\right)$ への変換関係 ${ }^{18)}$ 


$$
\xi_{i}=\xi_{i}\left(x_{1}, x_{2}, x_{3}, t\right), \quad \tau=t \quad(3-5)
$$

によって定義する。これにより、式 (3-2) は次式のよう に書き換えられる。

$$
\begin{gathered}
\int_{\bar{\Omega}} w_{i}\left(u_{i / \tau}+U_{j} u_{i / j}\right) J d \bar{\Omega}+\int_{\bar{\Omega}} \xi_{k, j} w_{i / k} \sigma_{i j} J d \bar{\Omega} \\
+\int_{\bar{\Omega}} \tilde{w}_{i}\left(u_{i / \tau}+U_{j} u_{i / j}-\xi_{k, j} \sigma_{i j / k}-f_{i}\right) J d \bar{\Omega} \\
=\int_{\Gamma} w_{i} \sigma_{i} I d \bar{\Gamma}+\int_{\bar{\Omega}} w_{i} f_{i} J \overline{d \Omega}
\end{gathered}
$$

ここで、 ()$_{/ \tau}=\partial / \partial \tau 、()_{/ i}=\partial / \partial \xi_{i} 、 d \Omega=J d \bar{\Omega} 、 d \Gamma=$ $I d \bar{\Gamma}$ 、を示し、JとIはそれぞれヤコビアン、 $U_{i}$ は次式の ように表される反変流速である。

$$
U_{i}=\xi_{i, t}+\xi_{i, j} u_{j}
$$

式 (3-6) はナビエ・ストークス方程式の厳密なぺトロ フ・ガラーキン表現なので、数值粘性はナビエ・ストーク ス方程式の全ての項に付加されることになる。しかし、 数值粘性を移流項に付加するだけで数值的な安定性を十 分に維持することが可能で、式 (3-6) を以下のように近 似化する。

$$
\begin{aligned}
\int_{\bar{\Omega}} w_{i} u_{i / \tau} J d \bar{\Omega} & +\int_{\bar{\Omega}}\left(w_{i}+\tilde{w}_{i}\right) U_{j} u_{i / j} J d \bar{\Omega}+\int_{\bar{\Omega}} \xi_{k, j} w_{i / k} \sigma_{i j} J d \bar{\Omega} \\
& =\int_{\bar{\Gamma}} w_{i} \sigma_{i} I d \bar{\Gamma}+\int_{\bar{\Omega}} w_{i} f_{i} J d \bar{\Omega} \quad(3-8)
\end{aligned}
$$

次に、4階 3 次の数值粘性を作るために、摄動関数 $\tilde{w}_{\mathrm{t}}$ を次のように定義する。

$$
\tilde{w}_{i}=-\frac{1}{3} \Delta \xi_{(j)}^{2} w_{i /(j j)}-\frac{1}{12} \alpha \Delta \xi_{(j)}^{3} \operatorname{sgn}\left(U_{(j)}\right) w_{i /(j j j)}
$$

ここで、 $\Delta \xi_{i}$ は写像領域での要素の長さ、 $\alpha$ は数值粘性の 強さを調整するパラメータである。またカッコ付き指標 は移流項の指標 $j$ と同じ数值を取るすのと定義する。

上記の摂動関数は標準重み関数の 2 階と 3 階の微分に より作られている。しかし、有限要素近似では線形形状 関数の使用がたいへん便利であるので、線形形状関数を 用いて高次精度の空間離散化を達成するために、以下の ような補助関数を採用する。

$$
\begin{aligned}
\omega_{i} & =J U_{j} u_{i / j} \\
\phi_{i(j)} & =\Delta \xi_{(j)}^{2} w_{i /(j j)}
\end{aligned}
$$

以上ょり、式 (2-3) 、(3-9)-(3-11) を使えば、式 (3-8) は次式のように表すことができる。

$$
\begin{gathered}
\int_{\bar{\Omega}} w_{i} u_{i / \tau} J d \bar{\Omega}+\int_{\bar{\Omega}}\left(w_{i} \omega_{i}-\frac{1}{3} J U_{j} \phi_{i(j)} u_{i / j}\right. \\
\left.-\frac{1}{12} \alpha \Delta \xi_{(j)} J\left|U_{j}\right| \phi_{i(j) /(j)} u_{i / j}\right) d \bar{\Omega}
\end{gathered}
$$

$+\int_{\bar{\Omega}} \frac{1}{R e} \xi_{k, j} w_{i / k}\left(\xi_{n, j} u_{i / n}+\xi_{n, i} u_{j / n}\right) J d \bar{\Omega}-\int_{\bar{\Omega}} \xi_{j, i} w_{i / j} p J d \bar{\Omega}$

$$
=\int_{\bar{\Gamma}} w_{i} \sigma_{i} I d \bar{\Gamma}+\int_{\bar{\Omega}} w_{i} f_{i} d \bar{\Omega}
$$

上記の方程式では、移流項の第 1 項だけに補助関数 $\omega_{i}$ が適用されているが、他の項へす適用してかまわない7)。 また、補助関数 (3-10) と (3-11) の重み付き残差方程式 はそれぞれ以下のようになる。

$$
\begin{gathered}
\int_{\bar{\Omega}} \bar{\omega}_{(i)} \omega_{i} d \bar{\Omega}=\int_{\bar{\Omega}} J U_{j} \bar{\omega}_{(i)} u_{i / j} d \bar{\Omega} \\
\int_{\bar{\Omega}} \bar{\phi}_{(i j)} \phi_{i(j)} d \bar{\Omega}=-\int_{\bar{\Omega}} \Delta \xi_{(j)}^{2} \bar{\phi}_{(i j) /(j)} w_{i /(j)} d \bar{\Omega} \\
\quad+\int_{\bar{\Gamma}} \Delta \xi_{(j)}^{2} \bar{\phi}_{(i j)} w_{i /(j)} n_{(j)} d \bar{\Gamma}
\end{gathered}
$$

\section{ここで、的(i) と市(ij) は標準重み関数を表す。}

次に、連続方程式と圧力のポアソン方程式に関する重 み付き残差方程式 (3-3) と (3-4) は、写像空間内でそれ ぞれ以下のようになる。

$$
\int_{\bar{\Omega}} \xi_{k, i} q u_{i / k} J d \bar{\Omega}=0
$$

$\int_{\bar{\Omega}} \xi_{k, i} \xi_{l, i} \bar{p}_{/ k} p_{/ l} J d \bar{\Omega}=\int_{\bar{\Omega}} \xi_{j, i} \bar{p} \tilde{u}_{i / j} J d \bar{\Omega}+\int_{\bar{\Gamma}} \xi_{l, i} \bar{p} p_{/ l} n_{i} I d \bar{\Gamma}$

以上が微分方程式系の弱表現である。これらは有限要 素近似によって離散系へ変換される。

\section{4. 有限要素方程式}

前章で示した各弱表現へ、通常の 4 角形要素を採用し た有限要素近似を行う。まず、式 (3-12)-(3-14) は次の ような離散方程式で表すことができる。

$\mathbf{W}^{\mathrm{t}} \mathbf{M} \mathbf{V}_{/ \tau}+\mathbf{W}^{\mathrm{t}} \mathbf{B}_{1} \boldsymbol{\Omega}-\boldsymbol{\Phi}^{\mathrm{t}} \mathbf{A}_{3} \mathbf{V}-\boldsymbol{\Phi}^{\mathrm{t}} \mathbf{A}_{\mathbf{4}} \mathbf{V}+\mathbf{W}^{\mathrm{t}} \mathbf{K V}$

$$
\begin{array}{ll}
-\mathbf{W}^{\mathrm{t}} \mathbf{C P}=\mathbf{W}^{\mathrm{t}} \mathbf{F} & (4-1) \\
\boldsymbol{\Omega}=\mathbf{M}_{0}^{-1} \mathbf{A}_{1} \mathbf{V} & (4-2) \\
\boldsymbol{\Phi}=-\mathbf{M}_{0}^{-1} \mathbf{B}_{2} \mathbf{W} & (4-3)
\end{array}
$$

ここで、 $\mathbf{V} 、 \mathbf{P} 、 \mathbf{W} 、 \boldsymbol{\Omega} 、 \boldsymbol{\Phi}$ は、それぞれ $u_{i} 、 p 、 w_{i} 、$ $\omega_{i} 、 \phi_{i j}$ に関する未知節点べクトル、F は外力のベクト ル、他のものはそれぞれ行列を表す。式 (4-2) と (4-3) を 式 (4-1) へ代入し、整理すると

$$
\mathrm{MV}_{/ \tau}+(\mathrm{N}+\mathrm{K}) \mathrm{V}-\mathbf{C P}=\mathbf{F}
$$

となり、移流項の行列 $\mathrm{N}$ は以下の行列の計算によって 与えられる。

$$
\mathbf{N}=\mathbf{B}_{1} \mathbf{M}_{0}^{-1} \mathbf{A}_{1}+\mathbf{B}_{2}^{\mathrm{t}} \mathbf{M}_{0}^{-\mathrm{t}} \mathbf{A}_{3}+\mathbf{B}_{2}^{\mathrm{t}} \mathbf{M}_{0}^{-\mathbf{t}} \mathbf{A}_{4} \quad(4-5)
$$


上記行列 $\mathbf{N}$ の右辺第 1 項と 2 項の和が移流項 $U_{j} u_{i / j}$ に関する 4 次精度の中心近似、第 3 項が 4 階 3 次の数值 粘性項をそれぞれ表現することになり、全体として上流 化が計られる。式(3-15) と(3-16) の有限要索方程式は、 それぞれ以下のように書くことができる。

$$
\begin{gathered}
\mathrm{HV}=\mathbf{0} \\
\mathbf{S P}=\mathbf{H} \tilde{\mathbf{V}}+\mathbf{G}
\end{gathered}
$$

ここで、 $\mathrm{S}$ と H は行列、 $\mathbf{G}$ は圧力の境界条件から得ら れるベクトルである。以上より、有限要素方程式 (4-4) と (4-7) を非生縮性の条件式 (4-6) を満たしながら逐次 計算を行ない、時間ステップごとに流速と圧力を決定し ていく。

\section{5. 数值計算例}

5.1 キャビティ内の流れ

この問題は計算スキームの有効性を調べるのに適して おり、多くの研究者によって計算されてきた。本論文で あ正方キャビティ内の流れの数值計算結果を示し、3 次 上流スキームの有效性を述べる。Fig.1にキャビティ内 流れの境界条件、Fig.2 に計算に使用した要素分割の一 例を示す。レイノルズ数は、代表流速 $U$ 、代表長さ $L$ お よび動粘性係数によって計算され、 $10^{3} 、 10^{4} 、 3 \times 10^{4}$ と して与えた。各レイノルズ数における要素数、最小メッ
シュ幅とパラメータ $\alpha$ の值を Table1 に示す。最小メッシュ 幅 $\Delta x_{\text {min }}$ は、 $\Delta x_{\text {min }}<1 / R e^{\frac{1}{2}}$ となるように設定した。ま た、2 次元計算では $R e \leq 10^{4}$ のと、ほぼ定常状態に達 するので、十分に要素分割がされているなら定常解に至 るのにパラメー夕 $\alpha$ 小さい䡛囲であれば、その大きさ にさほど依存しない。しかし、Re > 104では、非定常性 がしだいに強くなるので、数值粘性を小さくするために $\alpha=1$ とした。

Fig. 3 と 4 はレイノルズ数が $10^{3}$ と $10^{4}$ での無次元化 した流速べクトル、压力、キャビティ内の垂直と水平中 央線上での流速分布そして粒子の軌跡を示す。これらは ほぼ定常状態にある。垂直と水平中央線上の流速分布は 文献 19)の結果と比較したものであり、良い一致を示し ている。

Fig.5 はレイノルズ数が $3 \times 10^{4}$ での同様な結果であ る。これは無次元時間 $t=200$ まで計算したがまだ定常 状態には達していない。この結果では、中心に渦が 2 つ 現れ、それらが互いに回転している。一方、角では細か な渦が発生し、全体の運動としては乱流的な様相を示し ている。

\section{2 水路付きキャビティ内の流れ}

管路あるいは水路の壁面に設けられた急拡部内の流 れは、吉田ら ${ }^{24)} に よ り$ 数值計算が行われている問題であ る。Fig.6 は本論文で対象とする境界条件、Fig.7 に計算 に用いた要素分割を示す。

Table 1 Finite Elements and parameter $\alpha$

\begin{tabular}{rccc}
\hline Re & $10^{3}$ & $10^{4}$ & $3.0 \times 10^{4}$ \\
\hline Elements & 2500 & 2500 & 4900 \\
Minimum Mesh Size & $3.285 \times 10^{-3}$ & $2.194 \times 10^{-3}$ & $8.632 \times 10^{-4}$ \\
$\alpha$ & 3.0 & 3.0 & 1.0 \\
\hline
\end{tabular}

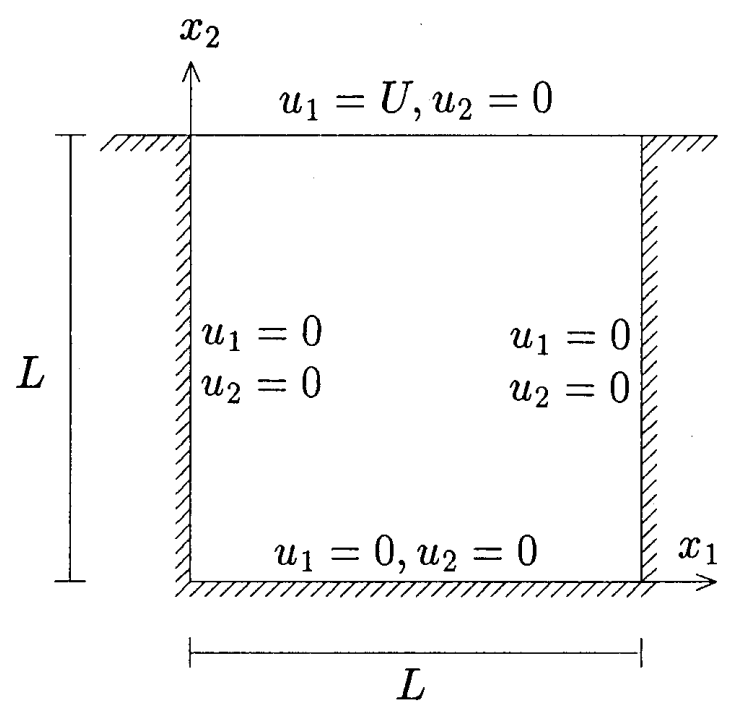

Fig.1 Boundary conditions for a square cavity.

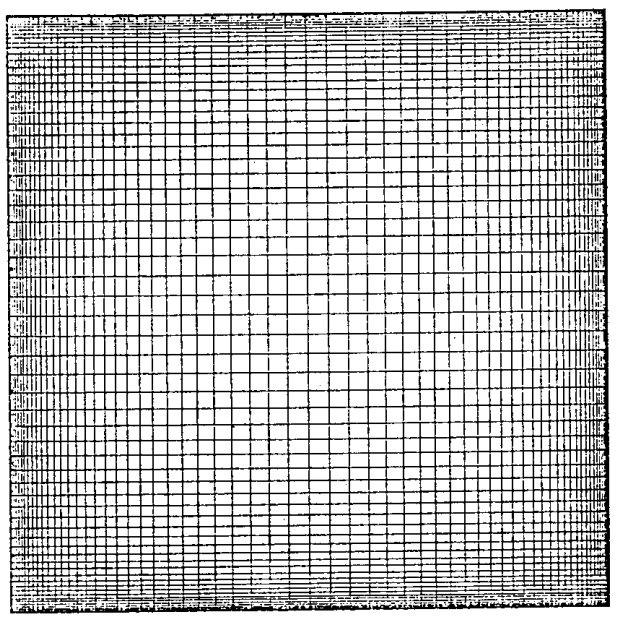

Fig.2 Finite element mesh used for computation of flow. 
$(a)$

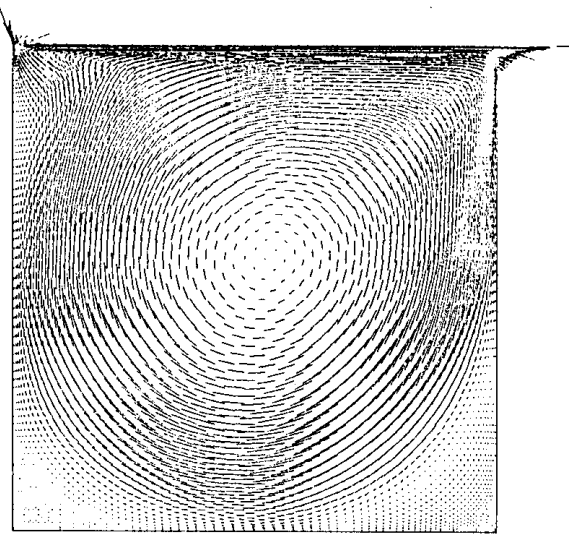

(c)

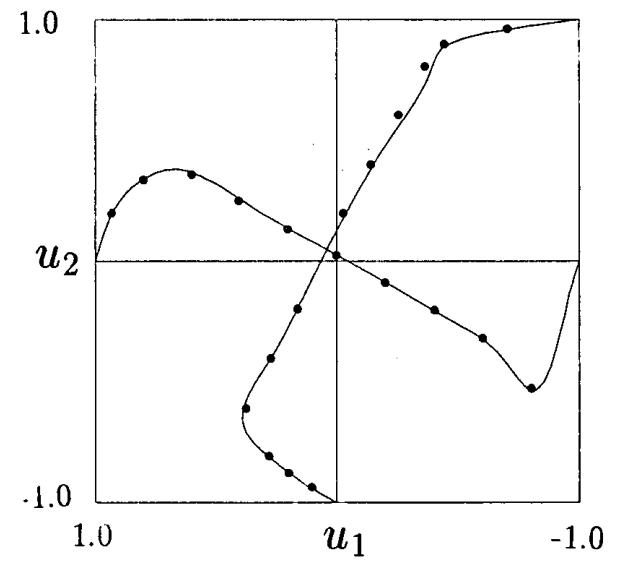

(b)

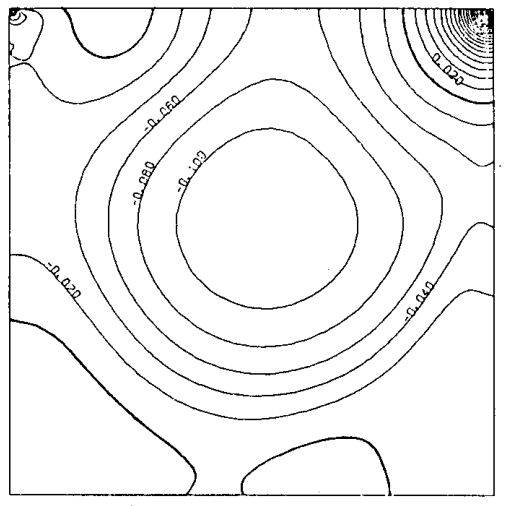

(d)

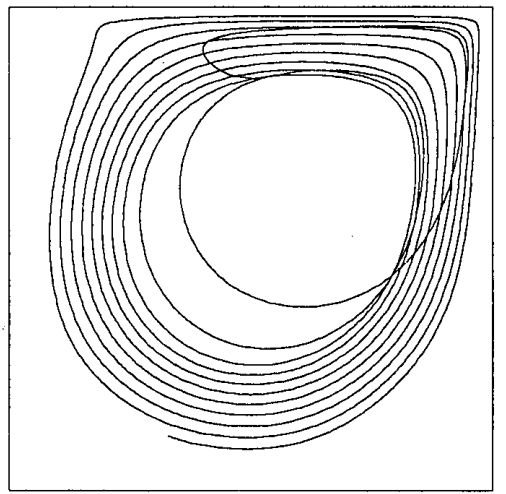

Fig. 3 Driven cavity flow at $\mathrm{Re}=10^{3}, \mathrm{t}=70$; (a) velocity vectors;(b) pressure contours; (c) velocity profiles on the vertical and horizontal center lines in the cavity, - presents, $\bullet$ Ghia et al.; (d) particle path.

(a)

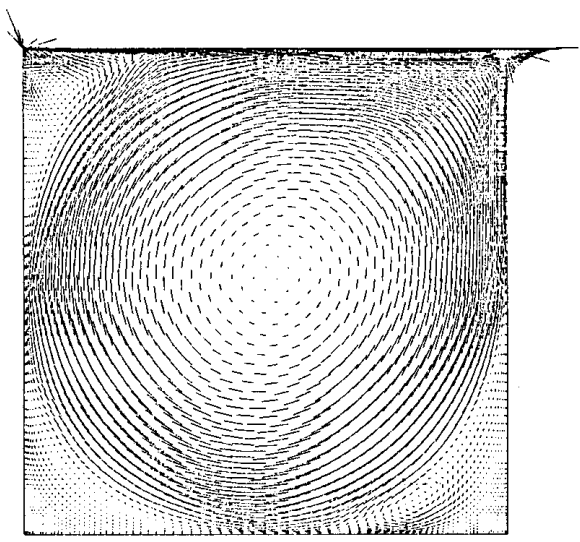

(c)

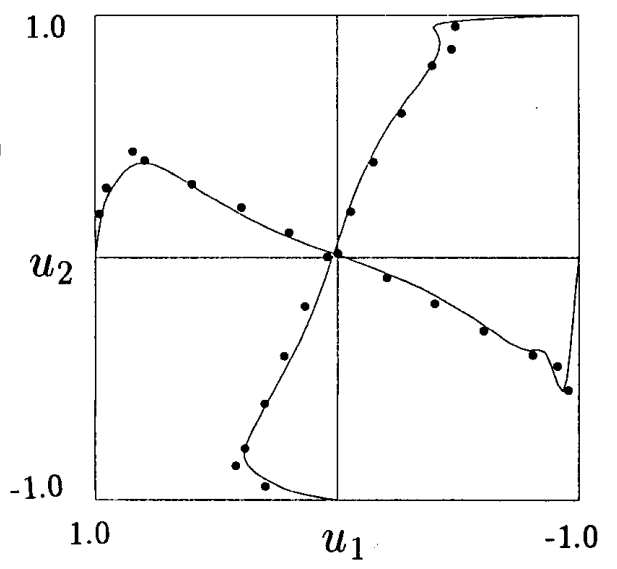

(b)

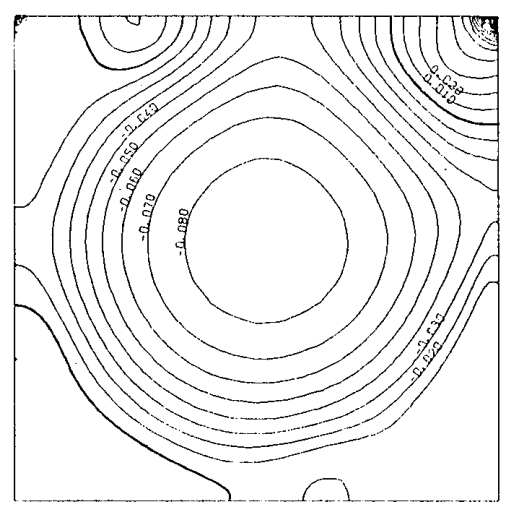

(d)

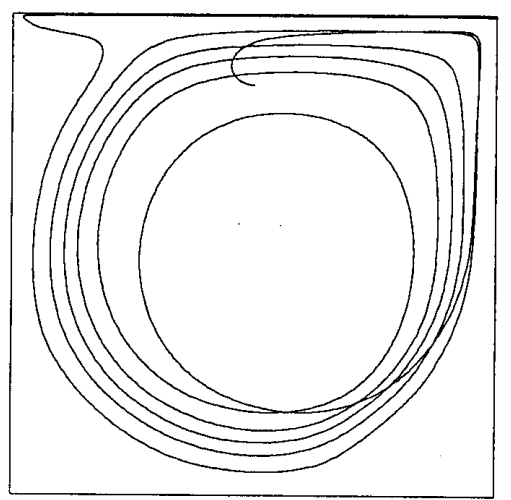

Fig.4 Driven cavity flow at $\operatorname{Re}=10^{4}, t=150$; (a) velocity vectors;(b) pressure contours; (c) velocity profiles on the vertical and horizontal center lines in the cavity, — presents, • Ghia et al.; (d) particle path. 
(a)

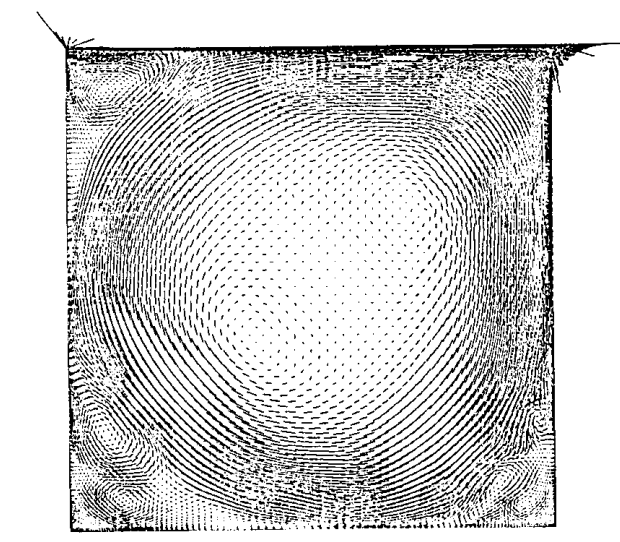

(c)

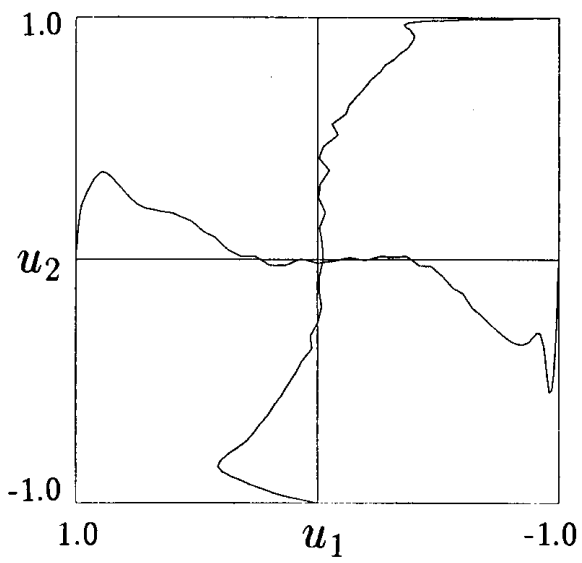

(b)

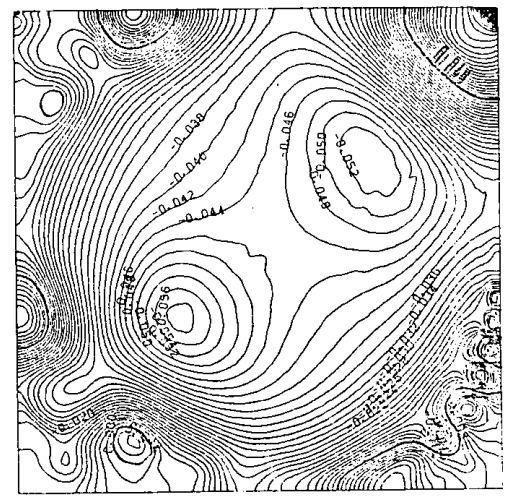

(d)

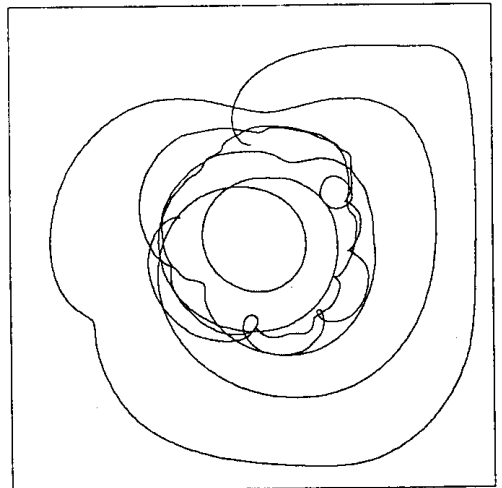

Fig. 5 Driven cavity flow at $R e=3.0 \times 10^{4}, t=200$; (a) velocity vectors; (b) pressure contours; (c) velocity profiles on the vertical and horizontal center lines in the cavity; (d) particle path.

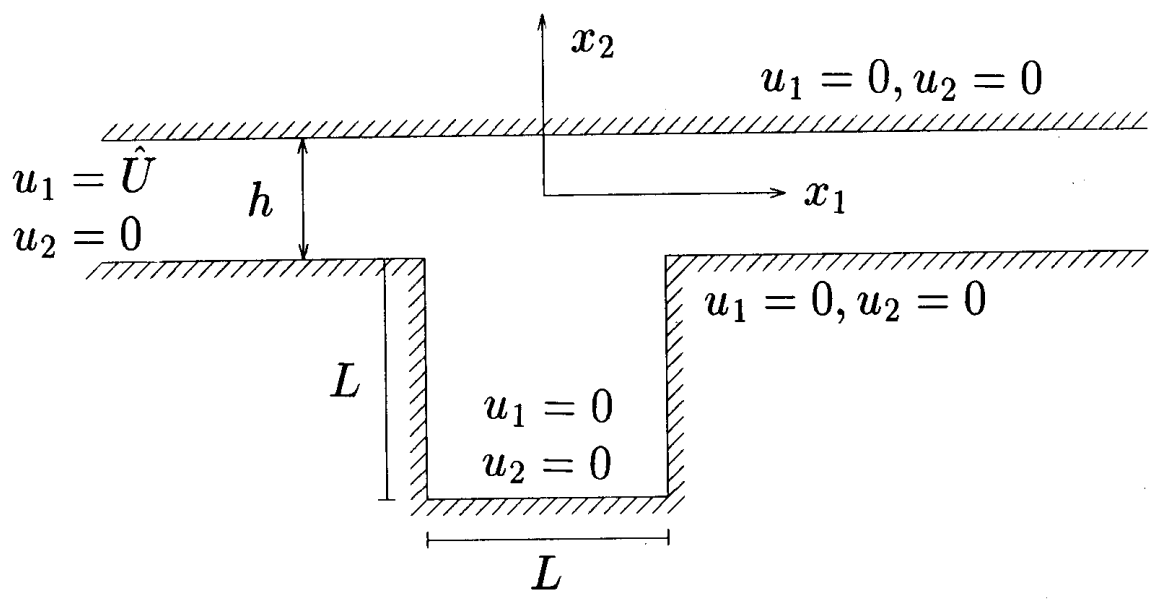

Fig.6 Boundary conditions for a square cavity with a channel.

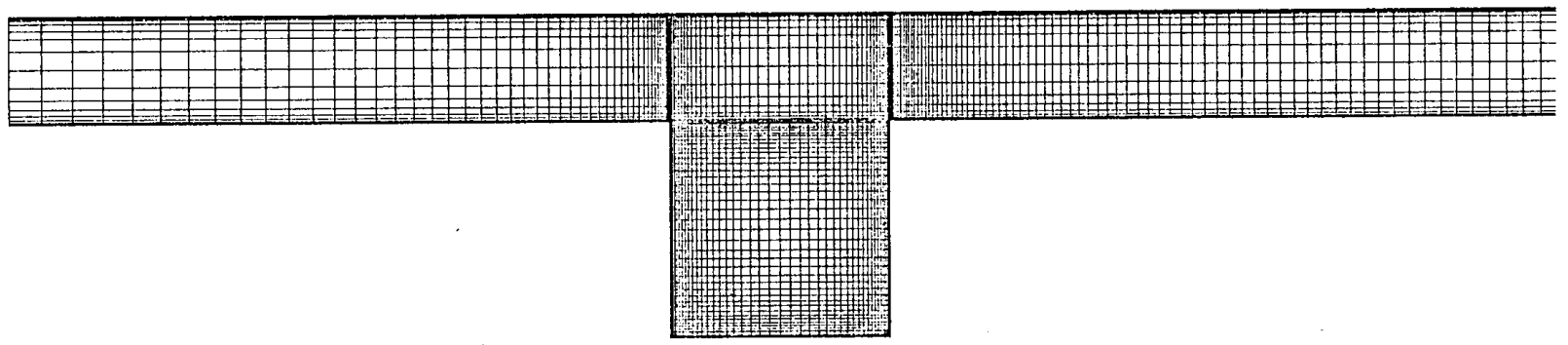

Fig.7 Finite element mesh used for computation of flow. 

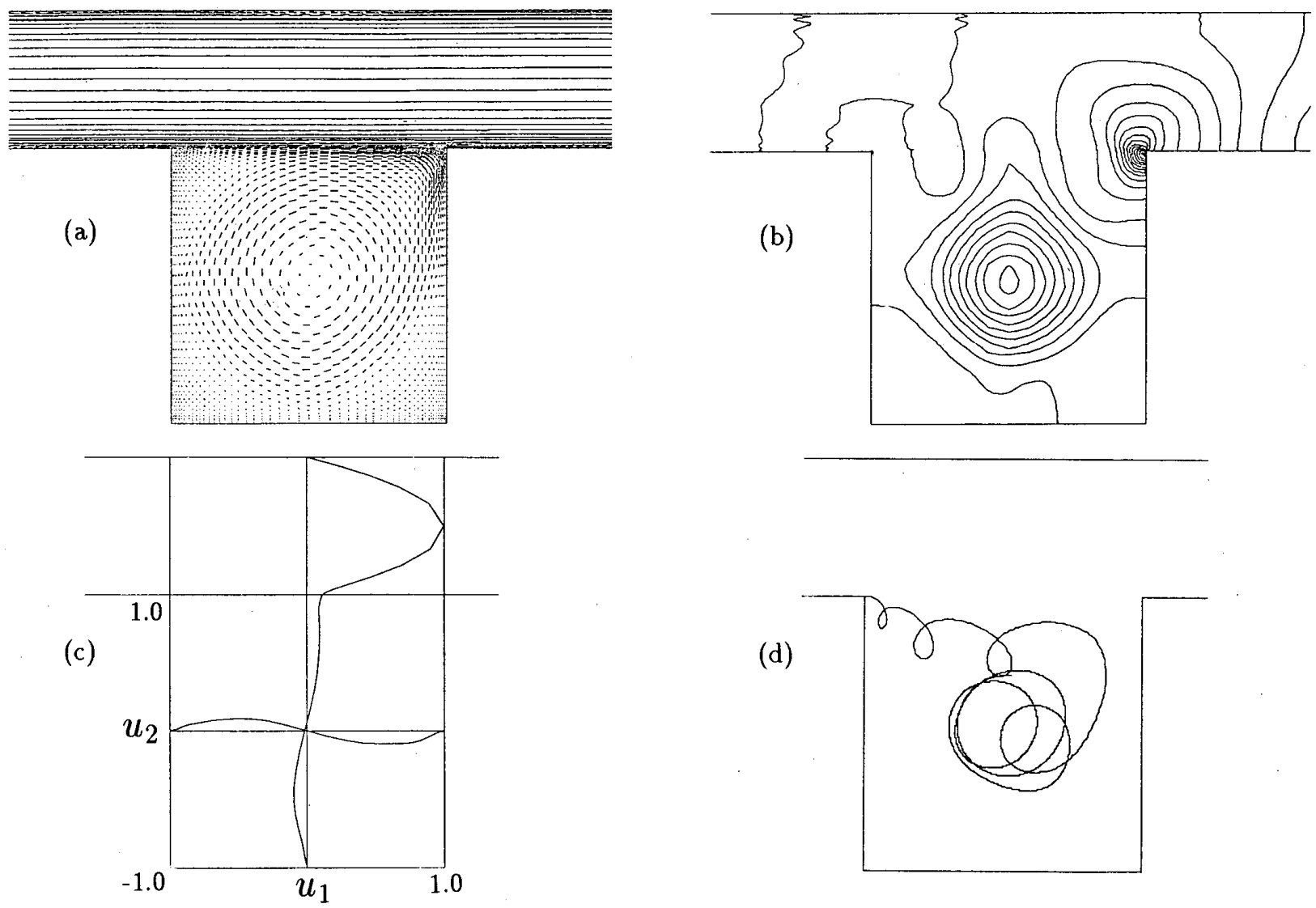

(d)

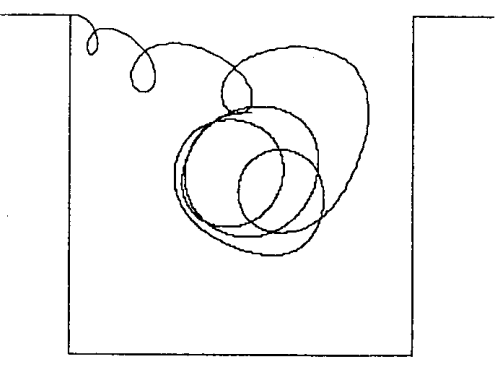

Fig. 8 Driven cavity flow with a channel at $R e=10^{4}, t=40$; (a) velocity vectors; (b) pressure contours; (c) velocity profiles on the vertical and horizontal center lines in the cavity; (d) particle path.

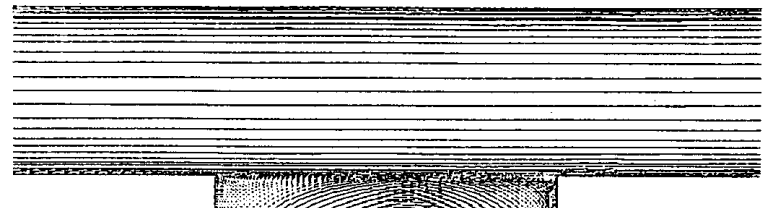

(a)

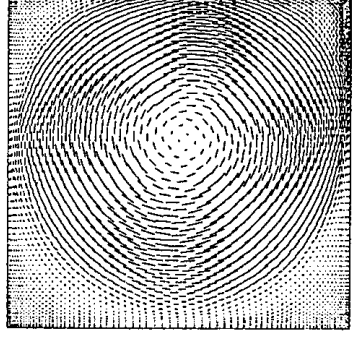

(c)

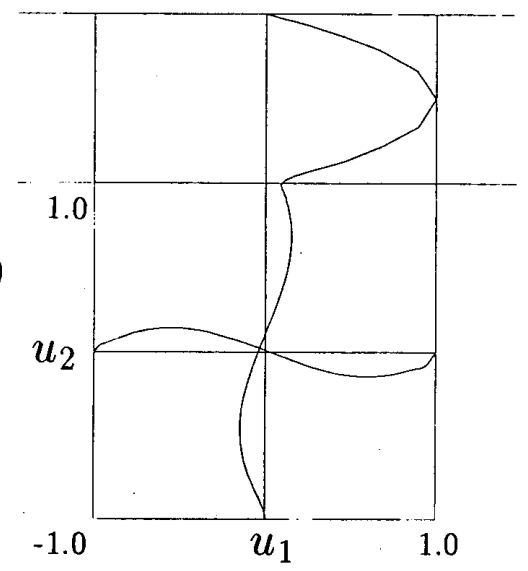

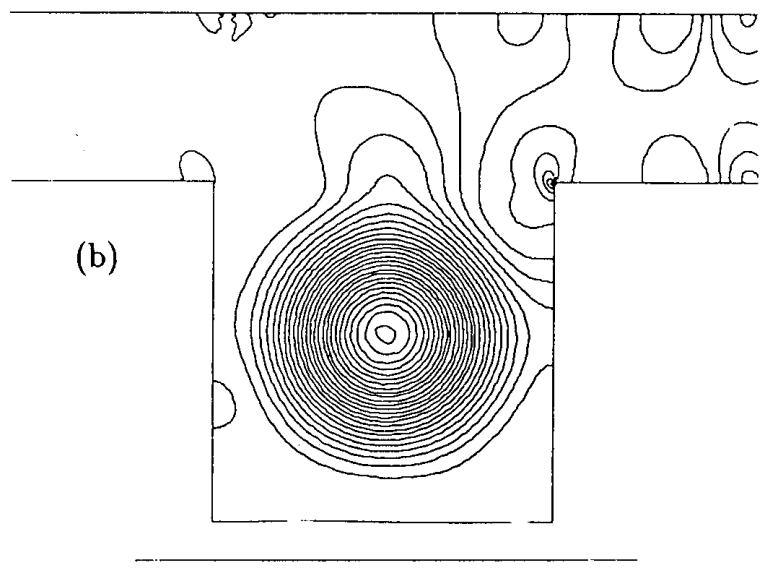

(d)

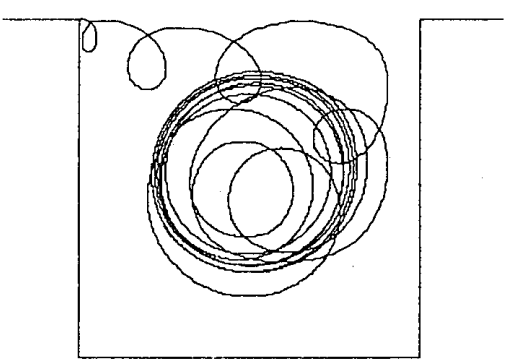

Fig.9 Driven cavity flow with a channel at $\mathrm{Re}=3.0 \times 10^{4}, \mathrm{t}=90$; (a) velocity vectors; (b) pressure contours; (c) velocity profiles on the vertical and horizontal center lines in the cavity; (d) particle path. 
流入境界で、

$$
\hat{U}=\frac{U}{h^{2}}\left(h^{2}-4 y^{2}\right), \quad h=\frac{L}{2}
$$

という放物流分布を与えた。各レイノルズ数における要 菜数、キャビティ内の最小メッシュ幅とパラメータ $\alpha$ の 值をTable 2 に示す。

Figs. 8,9 にレイノルズ数 $10^{4} 、 3 \times 10^{4}$ で、ほぼ定常状 態に達した時間での無次元化した流速べクトル、圧力、 キャビティ部分での垂直と水平中央線上の流速分布、粒 子の軌跡を示す。定常状態に達した後では、キャビティ 内の流れは水路の流れにはさほど影響を与えていない。

Fig.10にレイノルズ数 $3 \times 10^{4}$ での初期状態の流速分 布の一例を示す。この場合、キャビティ部分から水路内 に渦が膨れ上がっている様子が見られる。このような数 値結果は吉田ら 24$) の$ 結果にす見られ、同様な結果となっ ている。

Table 2 Finete Elements and parameter $\alpha$

\begin{tabular}{rcc}
\hline$R e$ & $10^{4}$ & $3.0 \times 10^{4}$ \\
\hline Elements & 4500 & 6500 \\
Minmum Mesh Size & $6.755 \times 10^{-3}$ & $2.194 \times 10^{-3}$ \\
$\alpha$ & 3.0 & 3.0 \\
\hline
\end{tabular}
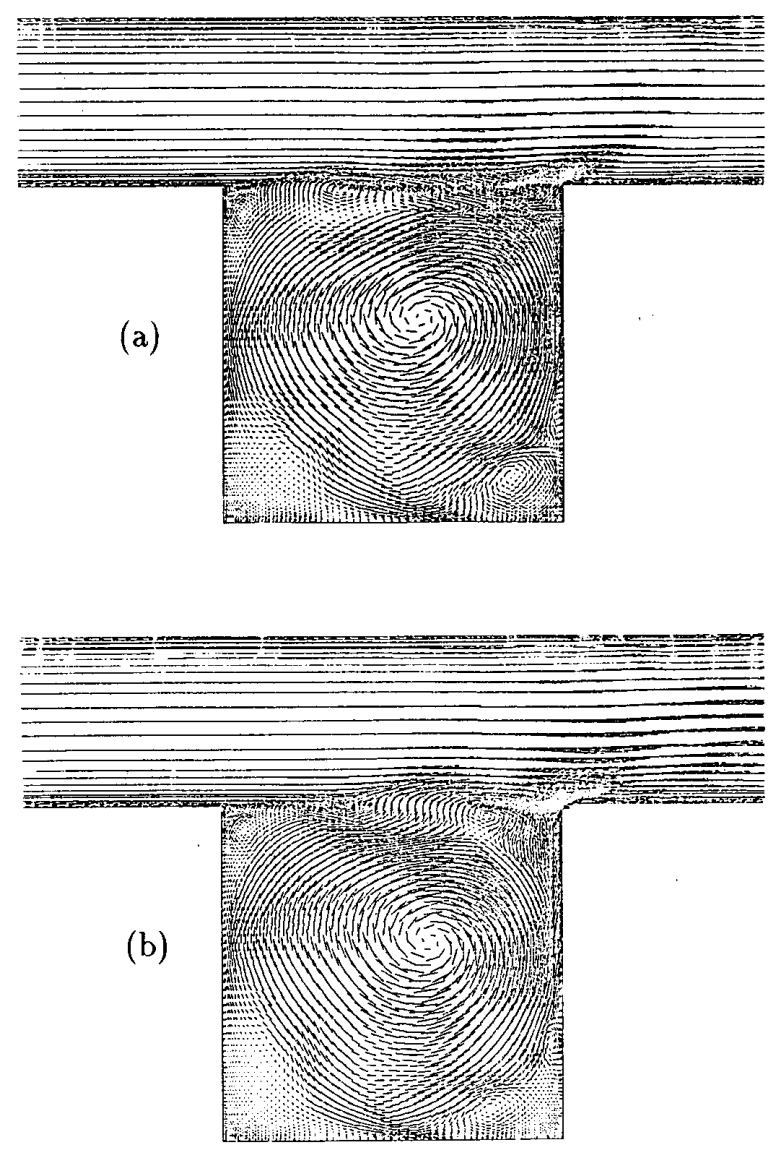

Fig. 10 Velocity vectors at $R e=3.0 \times 10^{4}$; (a) $t=14$;(b) $t=15$.
6. 結語

非圧縮性ナビエ・ストークス方程式の数値解を安定に 計算するための 3 次上流有限要素スキームを示してき た。この上流スキームの中に組み込まれる数值粘性は、 流速の 4 階微分で表現されており、ナビエ・ストークス 方程式の中の分子粘性とは直接比例しない。また修正重 み関数の中の高階微分項を離散化する上で補助関数を使 い、その微分の階数を下げる操作を行って、線形要素の 使用を可能にしている。

この 3 次上流有限要素スキームは乱流モデルを採用 していないので、数值的安定性を 4 階 3 次の数值粘性 によって維持しているが、この場合、計算メッシュを十 分に細かくとる必要があるなど制約が生じる。一方、数 值粘性項が分子粘性項と同じ 2 階微分によって作られる ような場合には、高レイノルズ数域での計算において、 その数值粘性が分子粘性を㠅い隠してしまうということ が生じかねない。このような場合には、見かけのレイ， ルズ数が低下してしまう。しかし、4階 3 次の数值粘性 では、分子粘性を直接的に覆い隠すということがないの で、高レイノルズ数域に至るまで精度良く計算できると いう利点がある。したがって、非圧縮粘性流れの計算手 法としてたいへん有効である。

本論文で示したキャビティ内の流れでは、レイノルズ 数 $10^{3} 、 10^{4}$ において他の解法の結果と良い一致を示すと ともに、高レイノルズ数流れの計算を十分に数值的安定 性を維持しながら計算することができた。

\section{参考文献}

1) 保原充、大宮司久明 編、数値流体力学 基礎亡応用、 東大出版会、1992.

2) Donea, J., Giuliani, S., Laval, H. and Quartapelle, L. : Finite Element Solution of the Unsteady NavierStokes Equations by a Fractional Step Method, Comput. Meths. Appl. Mech. Engrg., 30, 53-73, 1982.

3) Kawamura, T. and Kuwahara, K. : Computation of High Reynolds Number Flow Around a Circular Cylinder with Surface Roughness, AIAA-84-0340, AIAA 22nd Aerospace Science Meeting, 1984.

4) Leonard, B. P. : A Survey of Finite Differences with Upwinding for Numerical Modelling of the Incompressible Convective Diffusion Equation, Comput. Tech. Trans. and Turb. Flow, C. Taylor and K. Morgan eds., Pineridge Press, 1-35, 1981.

5) Tamura, T. and Kuwahara, K. : Direct Finite Difference Computation of Turbulent Flow Around a Circular Cylinder. Proc. of International Symposium on Computational Fluid Dynamics, 701-706, 1989.

(i) Kondo, N., Tosaka, N. and Nishimura, T. : Numeri- 
cal Simulation of Viscous Flows by the Third-Order Upwind Finite Element Method, Theoretical and Applied Mechanics, 39, University of Tokyo Press, 237-250, 1990. 7) Kondo, N., Tosaka, N. and Nishimura, T. : ThirdOrder Upwind Finite Element Formulations for Incompressible Viscous Flow Problems, Comput.Meths. Appl. Mech. Engrg., 93, 169-187, 1991.

8) Kondo, N., Tosaka, N. and Nishimura, T. : Computation of Incompressible Viscous Flows by the ThirdOrder Upwind Finite Element Method, Internat. J. Numer. Meths. Fluids, 15, 1013-1024, 1992.

9) Christie, L., Griffiths, D. F., Mitchell, A.R. and Zienkiewicz, O. C. : Finite Element Methods for Second Order Differential Equations with Significant First Derivative, Internat. J. Numer. Meths. Engrg., 10, 1389-1396, 1976.

10) Heinrich, J. C., Huyakorn, P. S., Zienkiewicz, O. C. and Michell, A. R. : A 'Upwind' Finite Element Scheme for Two-Dimensional Convective Transport Equations, Internat. J. Numer. Meths. Engrg., 11, 131-143, 1977. 11) Zienkiewicz, O. C. and Heinrich, J. T. : The Finite Element Method and Convective Problems in Fluid Mechanics, Finite Elements in Fluids, 3, R. H. Gallagher et al. eds., Jhon Wiley and Sons, 1-22, 1978.

12) Brooks, A. N. and Hughes, J. T. R. : Streamline Upwind/Petrov-Galerkin Formulations for Convective Dominated Flows with Particular Emphasis of the Incompressible Navier-Stokes Equations, Comput. Meths. Appl. Mech. Engrg., 32, 199-129, 1982.

13) Devloo, P., Oden, J. T. and Strouboulis, J. : Implimentation of an Adaptive Refinement Technique for the SUPG Algorithm, Comput. Meths. Appl. Mech. Engrg., 61, 339-358, 1987.

14) Tezduyar, T. E. and Ganjoo, D. K. : PetrovGalerkin Formulations with Weighting Functions Dependent Upon Spatial and Temporal Discretization: Application to transient convection-diffusion problems, Comput. Meths. Appl. Mech. Engrg., 59, 49-71, 1986. 15）角田和彦、登坂宣好、非定常非任縮粘性流九問題の 指数関数型 Petrov-Galerkin 有限要素法、日本建築学会 構造系論文報告集、第 439 号、189-198,1992.9.

16) Donea, J. : A Taylor-Galerkin Method for Convec- tive Transport Problem. Internat. J. Numer. Meths. Engrg., 20, 101-119, 1984.

17) Selmin, V., Donea, J. and Quartapelle, L. : Finite Element Methods for Nonlinear Advection, Comput. Meths. Appl. Mech. Éngrg., 52, 817-845, 1985.

18) Thompson, J. F., Marsi, Z. A. U. and Mastin, C. W. : Numerical Grid Generation, Foundation and application, North-Holland, Amsterdam, 1985.

19) Ghia, U., Ghia, K. N. and Shin, C. T. : High-Re Solutions for Incompressible Flow using the Navier-Stokes Equations and a Multigrid Method, J. Computational Physics, 48, 378-411, 1982.

20) Donea, J., Giuliani, S. and Laval, H. : TimeAccurate Solution of Advection-Diffusion Problems by Finite Elements, Comput. Meths Appl. Mech. Engrg., 45, 123-145, 1984.

21) Halow, F. h. and Welch, J. E. : Numerical Calculation of Time-Dependent Viscous Imcompressible Flow of Fluid with Free Surface, Phys. Fluid, 8, 2182-2189, 1965.

22) Donea, J. and Ouartapelle, L. : An Introduction to Finite Element Methods for Transient Advection Problems, Comp. Meths Appl. Mech. Engrg., 95, 169-203, 1992.

23) Iwatsu, R., Ishii, K. and Kuwahara, K. : Simulation of Transition to Turbulence in a Cubic Cavity, AIAA89-0040, AIAA 27th Aerospace Sience Meeting, 1989.

24) 吉田裕、野村卓史、矩形キャビティ内流孔問題の解 析における境界条件に関する一考察、土木学会論文報告 集、第 342 号、125-143, 1984.2.

25）金井恵理子、棚橋隆彦、非定常非圧縮性粘性流に適 する GSMAC 有限要素法 (第 2 報、高レイノルズ数に 安定な解法)、日本機械学会論文集 ( B 編)、53 巻 487 号、683-691、昭和 62 年 3 月。

26) 金井恵理子、棚橋隆彦、非定常非圧縮性粘性流に適 するGSMAC 有限要素法（第 2 報、高レイノルズ数に おける正方形キャビティ内流れ)、日本機械学会論文果 ( B 編)、53 巻 487 号、682-298、昭和 62 年 3 月.

27) 加納充浩、近藤典夫、西村敏雄、3 次上流有限要素 法によるキャビティ内流れ解析、構造工学における数値 解析法シシポジゥム論文集、第 17 巻、397-402、平成 5 年.

（1993 年 7 月 5 日原稿受理，1994 年 1 月 21 日採用決定） 